\title{
Introduction to the special issue in "Economics, Economic Policies and Sustainable Growth in the Wake of the Crisis"
}

\author{
Lisa Gianmoena ${ }^{1}$ \\ Published online: 19 February 2020 \\ (C) Springer-Verlag GmbH Germany, part of Springer Nature 2020
}

The tenth anniversary of the 2007-2009 financial crisis is ended and, although recent growth forecasts have improved, the world economy is recovering with tepid growth of private investment, increasing interest rates, and employment which are slowly returning to their pre-crisis levels. Indeed, these last 10 years have been characterized by massive disruptions in asset and credit markets, market's defaults, deep economic downturns with signification reductions on output, consumption, investment and employment. By the same token, Great Recession has induced higher inequalities among economies, in particular in those less resilient, leading the world economy to a great economic and social instability. Not surprisingly, the two themes, (i) inequality and (ii) resilience during the Great Recession, have been of great interest to scientific community. In particular, inequality in the distribution of income and wealth has become a major issue among the public opinion and has spurred a renewed interest in both the political and the academic debate, as it is considered to be "one of the biggest social, economic and political challenges of our time" (The Economist 2012; Stiglitz 2012; Piketty 2014; Atkinson 2015; Stiglitz 2015). Economic disparities, both between countries and individuals within a single country, appear to be very persistent and exert harmful effects on economic growth. At the same time, they increase the risk of running into a crisis, making economies less resilient.

In addition to the negative effects that the last financial crisis has had on the real economy, this global financial crisis has also been a wake-up call for rethinking macroeconomic principles, financial regulation and social aspects, prompting economists and scholars to reflect on the need for different economic policies. In particular, the Great Recession has had an extreme impact on macroeconomics as a discipline, leading economists to reconsider its micro economic foundation. It also forced theorists to better understand and incorporate financial sector into their models, the role of Government in the economy, and to elaborate policies to make economies more resilient.

Lisa Gianmoena

lisa.gianmoena@unipi.it

1 Department of Economics and Management, University of Pisa, Pisa, Italy 
In this view, in September 2016 the Polytechnic University of Marche hosted a conference entitled "Economy, economic policies and sustainable growth in the wake of the crisis". The main objective of this conference was to create a moment of debate among different academics on the lessons learned from the crisis and the subsequent long-term recession. Among the papers presented at the conference, we selected seven for this Special Issue. We believe that these seven papers well reflect the pluralistic and stimulating environment of the conference. These contributions are even more significant when viewed from a broader perspective, taking into account the aforementioned debate on rethinking macroeconomic principles/theories and on the capacity of macroeconomic models to explain the real world. This Special Issue aims to take stock of the latest theoretical and empirical advances in research, whose main aim is to promote and co-ordinate theoretical and applied research on economic growth and stability. Topics of interest include, but are not limited, to the challenges that monetary and public policy and the structure of the economic productivity have to face in the aftermath of the global financial crisis.

In this introduction we provide an overview to the Special Issue entitled "Economic Policies, Productivity and Sustainable Growth in the Wake of the Crisis" by detailing the main aim of each its contributions.

The first contribution by Giovanni Covi entitled "End of Sovereign-Bank Doom Loop in the European Union? The Bank Recovery and Resolution Directive" investigates whether the implementation of the new Bank Recovery and Resolution Directive (BRRD) has broken off the relationship between the default risk of banks and sovereigns, i.e. the "doom-loop". Using a panel with daily data on European banks and sovereigns ranging for the period 2012 to 2016 the author empirically evaluates whether the new regulatory standards, implemented through the European Banking Union, are able to reduce the link between sovereigns and bank default risk. He shows the existence of a two-way feedback loop between default risk of banks and sovereigns in the period 2012-2014, which becomes not significant in 2015-2016 after the starting of the European Banking Union.

The paper by Corrado di Guilmi and Laura Carvalho entitled "Technological unemployment and income inequality: a stock-flow consistent agent-based approach" proposes a stock-flow consistent agent-based model in order to analyze the effect of labor-saving technological progress on income and wealth/inequality distribution and, in turn, on macro aggregate dynamics. The main result is that technological unemployment has potentially destabilizing effects, leading to income inequality and aggregate instability that are amplified when the profit share of income increases. As reply to this effect, a way to stabilize the system is the introduction of a redistributive fiscal policy.

The article entitled "Long-run expectations in a learning-to-Forecast Experiment: A simulation Approach" by Annarita Cosante, Simone Alfarano, Eva Camacho-Cuena and Mauro Gallegati runs an experiment based on the well-known Learning-toForecast (LtF) design to study how subjects form their expectation on the evolution on the price of a financial asset in the short and a in the long run. More precisely, in each period an individual agent makes a forecast of next period's price as well as a forecast for all the 20 periods ahead. To understand how agents form and revise their expectation at different time of horizon is extremely important, given their relevance for monetary and fiscal policy in standard macroeconomic framework. The authors find that the realized price dynamics exhibits a tendency to converge to the asset's 
fundamental value. They also show that the elicitation of subjects' long-run expectations does not have major effects in the dynamics of short-run forecast; however, a clear influence of price dynamics on the formation and evolution of agents' long-run expectations emerges. In particular, the long-run price forecasts are anchored in the last observed price. The authors then propose a new computational algorithm, the Exploration-Exploitation Algorithm (EEA) to replicate short and long-run expectation properties observed in the experiment. The authors claim that the EEA performs very similar to the Heuristics Switching Model in describing the dynamics of short-run expectations and the price dynamics.

A second group of contributions addresses development in macroeconomic theory by proposing and reinterpreting some aspects in the field of growth models.

From a theoretical point of view, Daniele Tavani and Luca Zamparelli in their article entitled "Growth, Income Distribution, and the "Entrepreneurial State"" provide a novel and insightful contribution analyzing the role of the State as entrepreneur within the framework of Goodwin's (1967) model of growth cycle. Two specific functions of government are hypothesized: $i$ ) it collects income taxes in order to invest in infrastructure capital and, $i i$ ) it finances publicly funded research and development activities. The authors analyses the cases with and without induced technical change. It is shown that: $i$ ) provided that the output-elasticity of infrastructure is greater than the elasticity of labor productivity growth to public R\&D, there exists a tax rate that maximizes the labor share in the log-run. Consistent with the profit-driven nature of accumulation in Goodwin's model, this tax rate is lower than the growth-maximizing tax rate. $i i$ ) the long-run wage share is always increasing in the share of public spending in infrastructure. And finally iii ) differential tax rates on profit and wage income have an impact on the stability properties of the economy.

Alberto Botta in his paper entitled "The Short- and Long-run Inconsistency of the Expansionary Austerity Theory: A Post-Keynesian/Evolutionist Critique" deals with a relevant topic on the role of public sector in the economic growth. The author provides a critical analysis of the expansionary austerity theory presenting a simple theoretical model based on both the post-Keynesian and the evolutionary/institutionalist school. The model is able to capture some inconsistencies and the limited applicability of the theory that public sector retrenchment with well-designed austerity measures can increase aggregate output and promote short-term economic expansions in the context of long-term consolidation plans.

The paper by Enno Schröder entitled "Offshoring, employment and aggregate demand" presents an investigation of offshoring in a Keynes-Kalecki-type macroeconomic model, where offshoring is represented as labor saving, import-using technical change. In this framework it emerges that results depend primary on the behavior of firms' mark-up on unit costs. More precisely, when a firm's mark-up grows, then the scale effect of labor demand is negative, and offshoring reduces domestic demand and employment. On the other hand, when the mark-up remains constant, the net effect of offshoring on domestic demand and employment can be ambiguous and crucially dependent on export price elasticity.

Finally, the paper entitled "Consistency and Incompleteness in General Equilibrium Theory", proposed by Simone Landini, Mauro Gallegati and Barkley Rosser, draws some implications for the General Equilibrium Theory (GET) approach to the problems of consistency and completeness as underline in the G̈odel-Rosser theorems of 1930s. 
In particular, the authors argue that uniqueness and stability of equilibrium cannot be proved from the axioms of GET and stress this limitation as a consequence of the incompleteness of formal systems. Because the limitation of the axiomatic approach is intrinsic, the authors advocate a different approach to modeling, which they claim should be based on the empirical evidence.

In conclusion, the variety and the quality of the contributions included in this Special Issue demonstrate the fruitfulness, innovation and development placed within the conference, and we believe that all the papers in this Special Issues contribute to the advance of knowledge, with positive impact on the economy and the society as a whole. We hope that they will also inspire further research that attempts to unravel the complexity of the economic phenomena. Finally, we would like to thank the editorial board and all reviewers for their valuable comments and support, as well as all the participants at the conference in Ancona.

\section{References}

Atkinson AB (2015) Inequality: what can be done? Harvard University Press, Cambridge

Goodwin R (1967) “A Growth Cycle”, In: Carl Feinstein, editor, Socialism, capitalism, and economic growth. Cambridge, UK: Cambridge University Press

Piketty T (2014) Capital in the twenty-first century. The Belknap Press of Harvard University Press, Cambridge

Stiglitz JE (2012) The price of inequality: how today's divided society endangers our future. W. W, Norton \& Company, New York

Stiglitz JE (2015) The great divide: unequal societies and what we can do about them. W. W, Norton \& Company, New York

The Economist (2012) For richer, for poorer. Special report. The World Economy. The Economist 2-4

Publisher's note Springer Nature remains neutral with regard to jurisdictional claims in published maps and institutional affiliations. 